\title{
Uma questão de método: origens, limites e possibilidades da etnografia para a psicologia social ${ }^{1}$
}

\author{
Mauricio Rodrigues de Souza * \\ Instituto de Filosofia e Ciências Humanas da Universidade Federal do Pará (UFPA), Belém, PA, Brasil
}

\begin{abstract}
Resumo: 0 presente trabalho, eminentemente voltado à metodologia de pesquisa em psicologia social, organiza-se em torno de três objetivos: definir em maiores detalhes algumas das principais características da etnografia, realizar um breve percurso histórico acerca das suas origens como prática cientificamente legitimada e, finalmente, discutir a sua atual utilização. De maneira conclusiva, enfatiza não apenas os limites, mas também as possibilidades da prática etnográfica, sustentando que a experiência de estranhamento que tradicionalmente a caracterizou continua trazendo em si mesma tanto o dinamismo quanto o potencial crítico necessários para manter em movimento o pensamento sobre ou, se preferirmos, com a diferença.

Palavras-chave: metodologia, etnografia, alteridade.
\end{abstract}

A ideia para o presente trabalho se originou de um levantamento bibliográfico que acompanhou parte da produção científica brasileira direcionada ao tema da metodologia de pesquisa em psicologia social ao longo da última década (2002-2012). Pois bem, salvo exceções representadas por textos como os de M. J. Spink (2007) e Narita (2006), chamou a nossa atenção em tal movimento investigativo a pouca quantidade de trabalhos que fizessem referências mais explícitas à etnografia, ainda que, como apontam Tittoni e Jacques (1998), Sato e Souza (2001) e Gonçalves Filho (2003), esta se apresente como uma modalidade de pesquisa tradicional e costumeiramente utilizada pela psicologia social.

Um quadro como esse tornou inevitável o seguinte questionamento: quais as razões para essa diminuição da utilização da etnografia por parte dos estudos psicossociológicos atualmente publicados em nosso país? Por derivação, passamos também a nos perguntar: haveria em tal aparente abandono justificativas que sugerissem inadequações ou inconsistências na transposição de um método de uma área para outra (no caso, da antropologia para a psicologia social)? Ou, em uma palavra, teria esta mesma etnografia voltado (ou passado) a ser considerada apenas "coisa de antropólogo"?

Tais interrogações adquirem algumas implicações importantes, uma vez que nos remetem, dentre outras coisas, ao já tradicional debate acerca da necessidade de uma

1 Uma versão anterior e reduzida do presente artigo foi originalmente apresentada na forma de comunicação oral no grupo de trabalho Histórias da Produção de Conhecimento em Psicologia Social no Brasil, o qual teve lugar no XVII Encontro Nacional da Associação Brasileira de Psicologia Social - ABRAPSO (Florianópolis/SC, 2 a 5 de outubro de 2013).

* Autor correspondente: mrsouza@ufpa.br maior permeabilidade entre fronteiras disciplinares definidas tão ou mais por questões políticas do que epistemológicas stricto sensu. Nestes termos, também não nos parece descabido retornar a outras perguntas como: até onde, na atualidade da pesquisa acadêmica, a possível integração entre os diferentes saberes se apresenta mais como discurso do que como prática efetiva? Até onde estamos mesmo dispostos a abandonar nossas zonas de conforto departamentais e verdadeiramente dialogar com as diferenças?

É evidente que não temos aqui a intenção de responder de todo a questionamentos como esses, cujas amplas dimensões ultrapassariam em muito as possibilidades de um artigo. De qualquer forma, para além de nos remeter a tais questões de natureza transdisciplinar, entendemos que essa proposta de um debate acerca dos contatos entre psicologia social e etnografia adquire singular pertinência por outras razões. A primeira delas se ampara na tradição, no já longo e há pouco mencionado histórico de aproximações entre $\mathrm{si}^{2}$. Já a segunda se refere ao presente e, com ele,

2 Histórico esse cuja importância pode ser medida não somente pelo impacto e influência que deteve nas obras de pensadores do quilate de Bastide (1950/1974) e Lévi-Strauss $(1958,1962)$, mas também pela geração do ramo de pesquisas da etnopsicanálise, desenvolvido por Róheim (1967) e Devereux $(1972,1977,1980)$. Suas origens remontam a, pelo menos, dois momentos basilares. O primeiro deles está ligado ao próprio início da psicologia social como disciplina cientificamente reconhecida, com a chamada Escola Sociológica de Chicago nas primeiras décadas do século XX (Farr, 1999). Em tal contexto, a etnografia foi efetivamente privilegiada como instrumento de pesquisa tanto pela ecologia humana de Robert Park quanto pelo behaviorismo social e pelo interacionismo simbólico de George Mead e Harold Blumer (Deegan, 2001; Rock, 2001). Um segundo momento representativo desta já antiga tradição de contatos entre etnografia e psicologia social também se desenvolveu no início do século XX. Mais precisamente, na década de 1920, com as pesquisas de Bronislaw Malinowski entre os nativos da Nova Guiné (voltaremos a isto) e, a partir delas, com a publicação, pelo antropólogo polonês, do livro Sexo e Repressão na Sociedade Selvagem (Malinowski, 1927/1973). O livro de Malinowski, vale lembrar, colocava em cheque 
a livros como Writing at The Margin: Discourse between Anthropology and Medicine, de Arthur Kleinman, em que o valor de articulações entre antropologia, etnografia e áreas da saúde como a medicina é não somente mencionado, mas verdadeiramente defendido (Kleinman, 1996).

Em uma palavra, acreditamos que a relevância de um debate como o que propomos aqui se estabeleça na tentativa de superarmos o meramente descritivo e aparentemente particular de cada área em busca de diálogos que podem se revelar profícuos tanto para a psicologia social quanto para outras disciplinas, como a antropologia, aqui representada pela, mas de maneira alguma reduzida à, etnografia. É, portanto, levando isto em conta que o presente trabalho parte rumo a três objetivos principais.

$\mathrm{O}$ primeiro deles consiste em definir algumas das principais características da etnografia; o segundo se apresenta na realização de um breve percurso histórico acerca das suas origens como prática cientificamente legitimada, origens estas diretamente associadas aos avanços do funcionalismo antropológico britânico das primeiras décadas de $\mathrm{XX}$ e, em tal contexto, às pesquisas desenvolvidas por Bronislaw Malinowski. Finalmente, tencionamos discutir em um terceiro momento alguns aspectos da utilização da etnografia hoje, enfatizando aí os seus limites e possibilidades para os estudos psicossociológicos contemporâneos.

Antes de seguirmos em frente, porém, vale a pena acrescentar algo mais a esta introdução: trata-se da consciência de que o primeiro e o segundo objetivos colocados anteriormente não se apresentam exatamente como novidades. Afinal, a caracterização do conceito, origens e desenvolvimento da etnografia já foi realizada por diversos autores e pode ser encontrada sem grande dificuldade em variados manuais de ciências sociais no Brasil e no exterior. Contudo, incluímos tal movimento aqui e acreditamos que ele se justifique pela possibilidade de, no espaço de um único artigo, reunir questões por vezes colocadas de maneira esparsa em publicações que costumam ser pouco lidas pelo aluno ou profissional da psicologia. Ao mesmo tempo, entendemos que a recapitulação destes pressupostos se revele valiosa para uma melhor compreensão geral das nossas considerações finais, as quais propõem, ao mesmo tempo, diferenças e complementaridades entre o "antes" e o "agora" das inter-relações entre etnografia e psicologia social. Diante disto, passemos então a alguns comentários de caráter conceitual e histórico.

\footnotetext{
a hipótese freudiana da universalidade do Complexo de Édipo a partir da observação de que, entre os trobriandeses, a educação das crianças aparecia como tarefa não do pai biológico, mas do tio materno (relação avuncular), o que faria cair por terra o superdimensionamento do triângulo edipiano pautado na relação entre pai, mãe e filho. Tal ressalva gerou um polêmico debate com psicanalistas como Ernest Jones, debate este que, por sua vez, conduziu ao esclarecimento de que o que interessaria à psicanálise seria não exatamente a relação da criança com o pai de carne e osso, e sim a relação, de caráter simbólico, estabelecida entre o infante e a figura paterna, figura de lei e autoridade que independeria de uma filiação biológica mais direta (Backès-Clément, 1988; Godelier \& Hassoun, 1996).
}

\section{Acerca da etnografia: características, ori- gens e desenvolvimento}

De maneira a evitarmos possíveis confusões, uma vez que o rótulo "método etnográfico" pode e costuma abrigar variadas práticas e técnicas específicas e utilizadas por diversas áreas do conhecimento, compreendemos a etnografia aqui a partir da sua aproximação original com a antropologia e na qualidade de um método qualitativo de pesquisa que visa à descrição e o entendimento holístico de fenômenos culturais (e, com eles, dos significados sociais) presentes em grupos, comunidades ou instituições particulares de acordo com os próprios termos e atitudes daqueles que os vivenciam em seu cotidiano. Para tanto, levando em conta toda uma dimensão intersubjetiva que é tomada como parte inseparável do seu processo de trabalho, a etnografia pressupõe um contato não apenas bastante próximo, mas também frequente e prolongado com o outro, aliado à utilização de instrumentos como mapas, recenseamentos, quadros sinóticos, entrevistas mais ou menos diretivas, gravadores, equipamentos de fotografia e/ou filmagem, bem como diários, anotações de campo e, claro, a observação (direta ou) participante.

Como veremos em maiores detalhes adiante, as origens da etnografia como prática cientificamente legitimada parecem associadas aos estudos antropológicos de comunidades de pequeno porte na transição do século XIX ao XX. Contudo, tal metodologia foi posteriormente redirecionada também para o contexto das grandes cidades e reapropriada por disciplinas como, a sociologia e a psicologia social. O conhecimento etnográfico, porém, não é obtido ao acaso, e sim por um paciente trabalho que exige do pesquisador algo mais. Além da disponibilidade para um contato com o novo, com o inusitado, trata-se de uma predisposição a se manter continuamente atento ao detalhe de forma que este (um incidente trivial ou inesperado, por exemplo) se torne revelador. ${ }^{3}$.

Para um autor como Magnani (2009), a partir de tal discussão acerca das características da etnografia emergiriam ainda outros desdobramentos. Por exemplo, a necessária distinção entre prática etnográfica e experiência etnográfica. A primeira delas diria respeito ao trabalho cotidiano e sistemático do etnógrafo, trabalho, como vimos há pouco, não necessariamente pautado pela coleta obsessiva de detalhes, mas por uma atenção viva aos detalhes que vão sendo efetivamente coletados; já a segunda nos remeteria aos insights do pesquisador, àqueles momentos que, unindo as dimensões ao mesmo tempo objetiva e subjetiva do trabalho de campo, propiciariam a percepção de novos e interessantes contornos sobre os modos de vida dos

3 Importante acrescentar aqui, porém, que não se trata apenas de manter um foco obsessivo no acúmulo de traços culturais específicos, mas, como já alertara Lévi-Strauss (1958), que a atenção fornecida a eles se oriente rumo à possibilidade de que os diferentes fragmentos obtidos no trabalho etnográfico se aproximem e, assim, revelem delineamentos mais amplos acerca das práticas socioculturais que se pretende compreender. 
diferentes grupos estudados pelo etnógrafo ${ }^{4}$. De qualquer forma, cabe acrescentarmos que, embora rica na sua particularidade, a experiência etnográfica somente se torna possível mediante o contato paciente e contínuo com o outro. É nestes termos que podemos compreender a seguinte afirmação: "enquanto a prática é programada, contínua, a experiência é descontínua, imprevista. No entanto, esta induz àquela e uma depende da outra" (Magnani, 2009, p. 136).

Já o segundo desdobramento que passa a nos interessar aqui acrescenta ao primeiro a condição de que, na qualidade de método, a etnografia seja tomada em sentido amplo. Ou seja, nem restrita à qualidade de mera técnica a ser aplicada e nem tampouco como atitude ou atividade de campo específica. Com efeito, o pleno exercício do método etnográfico deve englobar: "as estratégias de contato e inserção no campo, condições tanto para a prática continuada como para a experiência etnográfica e que levam à escrita final" (Magnani, 2009, p. 136). Entretanto, tal meta não pode ser alcançada fora de uma necessária vinculação da etnografia a um quadro conceitual que a exceda, fornecendo, assim, a instrumentos como a entrevista e a observação participante um amparo teórico que justifique mesmo a sua existência e utilização.

Assim, uma vez brevemente definida em sua dimensão mais conceitual, retornemos agora às origens históricas da etnografia. Como veremos a seguir, estas remontam ao continente europeu e, mais especificamente, aos dilemas teóricos, metodológicos e éticos enfrentados pelos antropólogos ingleses na transição do século XIX ao XX.

\section{A antropologia britânica do início do século $X X$ e os primórdios da etnografia como atividade científica}

Segundo autores como Durham (1978), Firth (1960), Kuper (1978) e Stocking Junior (1992), a principal característica da antropologia britânica das primeiras décadas do século XX residiu em um esforço no sentido do acúmulo de dados, haja vista as generalizações conceituais evolucionistas e difusionistas até então vigentes começarem a se revelar inadequadas. Daí o ressurgimento do empirismo inglês naquele contexto em que os fatos deveriam falar mais que as teorias.

A partir de tais informações podemos melhor compreender a crescente necessidade da constituição de um trabalho de campo cientificamente consolidado, no que contribuiu, por exemplo, a expedição organizada

4 Outro acréscimo importante: a utilização aqui de expressões como "campo" ou "trabalho de campo" não deve induzir a uma errônea redução da etnografia à qualidade de atividade restrita a um território específico, englobando sim outros momentos do percurso do etnógrafo, como a escolha do tema, a pesquisa bibliográfica e, ainda, a escrita e o debate acerca do texto etnográfico, momentos que sugerem maior amplitude inclusive por não necessariamente ocorrerem no espaço geográfico onde são realizadas observações diretas ou participantes e também entrevistas com grupos das mais variadas naturezas (voltaremos a esta temática mais adiante). pela Universidade de Cambridge ao Estreito de Torres em 1898-99. Nela cientistas como Haddon, Rivers e Seligman, ainda que parcialmente dependentes das opiniões de informantes, davam um passo à frente rumo à pesquisa in loco - aquela orientada pelo contato efetivo com os povos estudados. Para além do terreno inglês, contudo, também a antropologia norte-americana, influenciada pela meticulosidade das pesquisas coordenadas por Franz Boas, passava por um processo semelhante.

Acompanhando essa nova tendência, caberia ao investigador de campo o dever de mais e mais se tornar um especialista ou scholar verdadeiramente treinado em seu ofício. Estava, portanto, configurado o contexto intelectual propício ao desenvolvimento das futuras pesquisas de Malinowski, o qual acabaria por consolidar a particularidade da etnografia em termos de um contato tanto íntimo quanto prolongado com o outro em seu próprio meio.

De qualquer forma, a grande chance de Malinowski iniciar seus estudos de campo somente apareceu em 1914, quando, então com 30 anos de idade, foi contemplado com uma bolsa que lhe possibilitou trabalhar por algumas semanas com os Mailu, da Melanésia. Na qualidade de súdito austríaco, porém, o início da Primeira Guerra Mundial acabou por inviabilizar o seu retorno ao Reino Unido. Assim, trazendo consigo certa insatisfação com os resultados da pesquisa anterior, tanto em termos de método quanto de resultados, Malinowski, após um breve retorno à Austrália, aportou nas ilhas Trobriand, da Nova Guiné, em junho de 1915, lá permanecendo até maio de 1916 e depois retornando em outubro de 1917 para nova estada de um ano.

As experiências realizadas ao longo desse período acabariam por se revelar cruciais para o desenvolvimento da etnografia como metodologia de trabalho que, mais tarde, tornaria Malinowski famoso graças à publicação de sete monografias entre 1922 e 1935. Como veremos a seguir, a introdução de Argonautas do Pacífico Ocidental desempenhou um papel fundamental em todo este processo.

\section{Com a palavra os argonautas: etnografia, subjetividade e método entre os nativos da Nova Guiné}

Conforme sugerido no parágrafo anterior, a introdução feita por Malinowski (1922/1978) a Argonautas do Pacífico Ocidental já há muito adquiriu a condição de "clássico" do métier antropológico, tendo sido, de maneira mais ou menos específica, objeto de uma grande quantidade de estudos publicados no Brasil e no exterior (Durham, 1978; Firth, 1960; Kuper, 1978; Stocking Junior, 1992). Com efeito, levando em conta a sua riqueza e importância, obviamente não temos aqui a pretensão de abarcá-la em sua totalidade, direcionando a nossa atenção para um ponto específico. Trata-se do estabelecimento e da exposição de princípios metodológicos regulares para a realização de um trabalho de campo considerado eficaz, incluindo-se aí a gênese e o papel a ser desempenhado pela observação participante. 
É assim que, com alguns comentários sobre os momentos iniciais da sua jornada - comentários relativos à chegada efetiva na aldeia, aos incipientes contatos com a comunidade trobriandesa com a qual conviveria ao longo dos meses seguintes e também sobre os receios e incertezas decorrentes da sua estada em meio a uma sociedade tão diferente da europeia -, já as primeiras páginas do escrito de Malinowski (1922/1978) passam a discorrer mais diretamente acerca das eventuais alternativas para se tentar alcançar uma coleta de dados minimamente satisfatória. É quando o autor propõe as três unidades que, segundo ele, comporiam os princípios metodológicos de uma boa etnografia.

Em primeiro lugar, o pesquisador deveria obter condições adequadas ao estudo etnográfico. Isto seria viável mediante $\mathrm{o}$ afastamento dos seus próprios pares em um contato o mais próximo e íntimo possível com os grupos dos quais se ocupará em seu trabalho. Para Malinowski (1922/1978), tal atitude forneceria a vantagem de um conhecimento e familiarização com a vida nativa bem superiores àqueles conseguidos por intermédio de informantes estrangeiros à cultura local, os quais, em muitos casos, agiriam de má vontade ou repletos de preconceitos.

De maneira complementar, a segunda recomendação feita por Malinowski (1922/1978) visando à realização de uma pesquisa de campo satisfatória reside na problematização da relação entre conhecimento teórico e práxis. Assim, ainda que reconheça que o domínio sobre critérios cientificamente validados apareça como condição sine qua non para um trabalho que pretenda ser levado a sério pela comunidade acadêmica, este autor insiste que, no caso da pesquisa etnográfica, caberia separar bem o joio do trigo - ou seja, a empiria da especulação. Neste sentido, para além do preconceito, tornar-se-ia essencial resgatar a lógica da visão de mundo própria ao nativo e a coerência da sua organização social.

Mais adiante, é novamente se posicionando contra o preconceito especulativo que Malinowski (1922/1978) defende a premissa fundamental que caracteriza a sua própria abordagem funcionalista. Ela se ampara em um ideal de pesquisa orientado para a totalidade e completude, sem conferir privilégios a características específicas da vida nativa, partindo em busca de leis e padrões gerais que fornecessem um contorno claro e firme das culturas estudadas. Enfim, uma espécie de gestalt integrativa entre o todo e as partes.

Precisamente aqui tem início a terceira das recomendações feitas por Malinowski (1922/1978) visando o aperfeiçoamento do ofício do etnógrafo. Trata-se da aplicação de métodos específicos de coleta, manipulação e registro de evidências. Quanto a este aspecto, uma pergunta-chave passa a ser a de como tentar alcançar leis culturais se tais parâmetros muitas vezes não se encontram formulados ou cristalizados entre os nativos. A resposta de Malinowski (1922/1978) é clara: coletando dados palpáveis sobre os fatos observados para, a partir daí, formular inferências mais gerais. Temos, assim, o método de documentação estatística por evidência concreta.
Dessa forma, sugere Malinowski (1922/1978), ao invés de questionamentos abstratos, mais valeria ao pesquisador tomar como referência um acontecimento em particular - um crime, por exemplo - e, em seguida, interpelar a comunidade sobre quais mandamentos ditados pela sua tradição definiriam procedimentos mais ou menos padronizados em relação ao ocorrido. Então, uma vez que as reações individuais seriam orientadas pelo fato social coercitivo, o mesmo pesquisador poderia, em um movimento indutivo, juntar opiniões e, organizando-as em um todo coerente, definir princípios ordenadores da cultura.

Ao defender a construção de uma etnografia genuinamente científica, porém, Malinowski (1922/1978) parece reconhecer os limites da empiria ao procurar associá-la a uma característica que considera positiva em alguns dos trabalhos que o precederam: a apresentação dos fatos íntimos do cotidiano nativo, traço menos permeado pela objetividade e somente alcançável por intermédio de uma vivência estreita e prolongada com o outro. Tratase, portanto, de transformar o verbo em carne e sangue, preenchendo o esqueleto teórico e abstrato com a realidade proporcionada pelos risos e lágrimas característicos das relações humanas.

Malinowski (1922/1978) denomina de imponderáveis da vida real esses anteriormente referidos fenômenos impassíveis de registro estatístico, mas cuja importância residiria na sua qualidade de cimento social. Daí o clamor pela atenção do pesquisador aos aspectos íntimos da vida grupal, diferente do quadro frio das relações sociais apresentadas em separado do seu contexto fenomênico original. Com isto, também atos aparentemente prosaicos, como os rituais e confraternizações, deveriam ser apresentados segundo o seu próprio tom e detalhes específicos, e não somente como esboços gerais.

Ainda assim, todo um esforço deveria ser feito no sentido de deixar os dados falarem por si mesmos. De que maneira? Registrando por escrito a observação dos fatos desde os primeiros contatos e logo em seguida à sua ocorrência. Mais ainda, paralelamente às anotações sobre os comportamentos mais típicos (ditados pelas regras da tradição), caberia registrar aqueles ligeira ou acentuadamente desviantes. Para a realização desta tarefa, nada mais apropriado do que o diário etnográfico, exaltado aqui como instrumento ideal e companheiro de viagem.

De qualquer forma, é novamente buscando aproximar as dimensões objetiva e subjetiva da pesquisa de campo que, mais adiante, Malinowski (1922/1978) nos apresenta a observação participante como movimento do etnógrafo visando uma interação efetiva e profunda com o nativo de maneira a melhor reconstruir a sua realidade. Nestes termos, este autor recomenda aos seus leitores que, vez ou outra, deixando de lado caderno, lápis e máquina fotográfi$\mathrm{ca}$ - objetos que caracterizariam uma clara separação entre o universo do pesquisador e aquele dos povos estudados -, tomassem parte como qualquer outro integrante local nas cerimônias, brincadeiras, jogos ou conversas comunitárias. 
Alcançamos então o que se constituiria, segundo Malinowski (1922/1978), no terceiro e último objetivo da etnografia: a decifração do "espírito" do nativo, incorporado nas ideias e definições construídas por si acerca do seu universo cultural. Consciente de que tal objeto poderia soar demasiado vago ou indefinido, o autor sustenta em sua defesa certa estereotipia dos pensamentos e emoções individuais, os quais seriam antecipadamente configurados por intermédio da tradição, da linguagem e de diversas instituições (como aquelas ligadas à economia ou à religião, por exemplo). Assim, caberia ao pesquisador o reestabelecimento desta vinculação entre o particular e o coletivo pela apresentação de termos de classificação advindos dos próprios nativos e/ou pela citação literal de asserções importantes também produzidas por eles.

Em seguida, demonstrando, porém, uma preocupação de ordem hermenêutica referendada pela sua própria experiência etnográfica e bem de acordo com o tipo de raciocínio metodológico que adota, Malinowski (1922/1978) enfatiza a necessidade de o etnógrafo dar um passo adiante nessa linha de ação. Afinal, a simples tradução direta em muitos casos destituiria o termo nativo de várias das suas características essenciais. Já a sua preservação, ao contrário, dependeria do aprendizado da língua nativa por parte do pesquisador, aprendizado que o habilitaria a ser capaz de, escrevendo (e mesmo raciocinando) em tal idioma, utilizar este corpus inscriptionum como instrumento investigativo, reproduzindo assim, da forma mais fidedigna possível, a mentalidade do outro.

A introdução ao mesmo tempo subjetiva e metodológica de Malinowski (1922/1978) chega então ao seu fim, deixando, porém, um desafio que, ao longo das décadas seguintes, viria a ser aceito não somente pelas novas gerações de antropólogos ao redor do mundo, mas também pelos primeiros psicólogos sociais formados na tradição do interacionismo simbólico vinculado à Escola Sociológica de Chicago (Coulon, 1995; M. J. Spink, 2007; P. K. Spink, 2003). Trata-se de conciliar subjetividade e método em uma pesquisa etnográfica cuja pretensão totalizante visava abarcar não só a estrutura social, mas o próprio espírito ou "ponto de vista" do nativo. Como interpretá-la? Seria coerente em si mesma ou se mostraria perdida a meio caminho entre influências de natureza, ao mesmo tempo, romântica e positivista?

\section{Ressalvas contemporâneas ao projeto etnográfico}

Com efeito, em que pese a sua inegável contribuição para o desenvolvimento sistemático da pesquisa in loco, é certo que o modelo etnográfico proposto por Malinowski se tornou alvo de ressalvas de variadas naturezas, em particular a partir da década de 1960 , a qual presenciou tanto a descolonização de territórios ingleses e franceses até então "etnografáveis" quanto a rebelião dos tradicionais "objetos" destas pesquisas. Tais críticas, de cunho ao mesmo tempo teórico, ético e técnico, apareceram a reboque de acalorados debates acerca das noções de identidade e de autoridade no trabalho de campo.

Nesses termos, a partir da reapropriação do referencial teórico da hermenêutica filosófica por parte do interpretativismo de Geertz (1973) - e, junto consigo, da dimensão histórica presente em uma agora não mais "asséptica" relação entre "sujeito" e "objeto" do conhecimento -, uma série de antropólogos passou a questionar a legitimidade da voz uníssona do etnógrafo acerca de padrões culturais distintos do seu, especialmente com o crescimento do processo de globalização das informações na sociedade contemporânea. Ou seja, temos aí uma epistemologia da interpretação etnográfica que aposta na afirmação de que o discurso racional não está separado nem de conteúdos valorativos e nem tampouco de relações de poder, enfatizando as várias estratégias retóricas do texto etnográfico supostamente "objetivo" mascaradas pela ênfase convencional na sua dimensão puramente semântica. Destacam-se em tal contexto trabalhos como os de Clifford (1988), Clifford e Marcus (1986), Marcus e Fischer (1986) e Stocking Junior (1992).

Também filiada a esse quadro aproximativo entre filosofia e ciências sociais aparece a proposta da antropologia simétrica de Latour $(1989,1991)$, balizada na ideia de uma dissolução das assimetrias tradicionalmente constitutivas da atividade de pesquisa, assimetrias estas expressas na disparidade ou hierarquização dos discursos do "sujeito" e "objeto" do conhecimento. Isto em virtude de os "objetos" passarem a ser pensados sob o signo da multiplicidade e nas suas articulações com diferentes dimensões e momentos da própria pesquisa.

Algumas consequências diretas dessa perspectiva aparecem, por exemplo, na proposta de um estranhamento do já enraizado, tanto em termos conceituais quanto no que se refere aos modos como os cientistas se relacionam no exercício da sua atividade. Tais consequências aparecem também na abertura para a possibilidade de que, na qualidade de pesquisadores, coloquemo-nos entre o dado naturalizado e o que é construído tanto sobre o outro quanto sobre nós mesmos. É neste sentido que, de acordo com Latour $(1989,1991)$, o dado e o construído podem e devem ser tomados como simultâneos, mutuamente implicados e na qualidade de pressuposições recíprocas.

Evidentemente, a perspectiva defendida por Latour $(1989,1991)$ não se pauta em algum ideal de que seria possível (e mesmo desejável) alcançar absolutas harmonia e igualdade no trabalho científico, também ele marcado por grandes conflitos em termos de forças e interesses contrastantes. Assim, de maneira a evitar cair na mesma armadilha que critica, o autor francês considera: em primeiro lugar, que o oposto de uma grande divisão não se revelaria em uma grande unidade; em segundo, que esta há pouco referida noção de simetria não funcionaria como chave para o alcance de alguma "unidade perdida"; finalmente, que o contraponto em relação aos grandes divisores apareceria nas pequenas multiplicidades. Em uma palavra, para a abordagem latouriana da ideia de simetria o problema não é ser dois, mas ser apenas dois. 
Ao mesmo tempo, a solução para tal dilema não passaria pela volta ao um ou para uma espécie de tudo ou nada no qual sairíamos de um movimento do tipo "da(s) identidade(s) rumo à relação" para outro do tipo "da relação para a(s) identidade(s)" se, a despeito da aparente inversão dos termos, tais identidades de pesquisador e de nativo permanecerem tomadas em um sentido cristalizado. Portanto, para além de purificações ou naturalizações da tradicional relação entre sujeito e objeto do conhecimento, a proposta de Latour $(1989,1991)$, de natureza propositalmente provocativa, é pensar a atividade científica como atividade eminentemente relacional e que não pressuponha ou gere identidades fixistas nem a priori e nem tampouco a posteriori.

É nesses termos que, como vimos há pouco, simetrizar para Latour $(1989,1991)$ não significa esquecer desigualdades. Ao contrário, trata-se de levá-las tão a sério a ponto de, problematizando-as, tornarmos a "nossa" própria sociedade tão "antropologizável" quanto a "deles". E mais: utilizando para tanto os conceitos "deles" como (res)significadores em potencial dos conceitos e categorias com os quais costumamos analisar os nossos "outros", conceitos e categorias estes que, a partir do confronto com a alteridade, tanto podem se revelar gastos ou cristalizados quanto sofrer uma preciosa e recorrentemente necessária revitalização.

Tais ressalvas ao projeto etnográfico já há muito exederam, porém, o espaço mais restrito dos departamentos de antropologia e filosofia da ciência e vêm adquirindo novos contornos também entre os psicólogos sociais ao longo das três últimas décadas. Como aponta Farr (1999), isto se dá na esteira de todo um movimento crítico em relação à orientação positivista que demarcou as origens da psicossociologia como disciplina. É nestes termos que, em seu elucidativo trabalho acerca das tendências emergentes nesta área de estudos em particular, Montero (1996) nos fala de um questionamento da ideia moderna de neutralidade do conhecimento. Portanto, conduz-nos também à presença de intenções e tendências no discurso da verdade, questões abordadas por um paradigma de ordem relativista mais claramente percebido a partir da década de 1980, mas cujas raízes remontariam aos primórdios da psicologia social.

Ainda para Montero (1996), esse paradigma se expressaria em variadas características inter-relacionadas. Em primeiro lugar, na desnaturalização dos objetos e na crítica a modelos representacionistas que, próximos a ideais fixistas como os de "origem" ou "identidade", congelariam a realidade sem levar em conta a dimensão histórica dos fenômenos psicossociais. Logo, junto ao caráter transcendente de regras metodológicas que se consideram gerais ou atemporais, passa a ser posta em xeque aqui qualquer noção neutra, asséptica, objetiva ou atemporal de "verdade", a qual se torna vinculada ao cotidiano e, com ele, a diferentes e dinâmicas possibilidades de negociação interpretativa. Por derivação, também se faz presente no atual paradigma relativista em psicologia social a noção de que a realidade nada seria senão uma construção coletiva, conflitiva e intercambiável de acordo com as flutuações inerentes à linguagem e aos contatos entre indivíduo e sociedade.

Mais uma vez levando em conta as restrições impostas pelo espaço de um artigo, eis aí apresentadas em termos bem gerais (sem que isto signifique, porém, qualquer desconsideração quanto ao fato de que há distintas etnografias, cujos objetos, objetivos, particularidades e alcance variaram e ainda variam bastante desde as pretensões totalizantes do funcionalismo malinowskiano) algumas ressalvas, limites e desafios contemporâneos ao projeto etnográfico. Tais demandas e reconfigurações de cunho, ao mesmo tempo, teórico, metodológico e ético conduziram a inovadoras propostas que atendem por nomes como construcionismo, cartografia, genealogia e teoria do ator-rede, todas elas marcadas por discursos avessos à tradicional equação entre pesquisa de campo, cientificismo e dominação (Arendt, 2008; Kastrup, 2007; P. K. Spink, 2003; Silva, 2004).

A despeito do seu caráter também multifacetado, tomemos alguns princípios do construcionismo como exemplo do contraponto há pouco mencionado entre tais tendências da psicologia social contemporânea e a etnografia. Neste sentido, como aponta P. K. Spink (2003), à medida que o foco construcionista incide sobre eventos no tempo, e não sobre fotografias congeladas, o "campo" ou os lugares da pesquisa passam a ser compreendidos como produtos sociais, e não como "dados" ou realidades independentes do pesquisador. De maneira correlata, para além da qualidade de um lugar geográfico espacialmente definido rumo ao qual este mesmo pesquisador se deslocaria para efetuar os seus estudos, o "campo" passa a ser visto como a situação (ou o argumento) de um assunto em determinado tempo e contexto, e o entrar (ou estar) no "campo" de uma pesquisa passa a ser pensado como a inserção no debate sobre este mesmo assunto. Com isto, também se tornam interessantes para a pesquisa tanto a atribuição de relevância aos temas a serem estudados quanto, por conseguinte, os posicionamentos tomados diante deles.

Portanto, o contraponto estabelecido aqui se dá entre uma dimensão material e outra social do "campo" (ou seja, a sua materialidade), considerando-se, neste segundo caso, que o assunto engloba o campo, e não vice-versa. Afinal, o meio não somente conta histórias, mas detém também as suas próprias. Nesta mesma perspectiva, ao levar em conta a concorrência entre os diferentes discursos envolvidos no cotidiano da atividade de pesquisa, esta aparece, no construtivismo, na qualidade de recorte, debate ou negociação (e não imposição) de sentido ou valor, já que, se o "campo" não é um lugar específico, então haveria múltiplos e concorrentes campos. Desta forma, como dar conta de todos? Como pretender que um discurso (ou seja, o discurso específico de determinado pesquisador) seja "o" verdadeiro? Por extensão, são postas em relevo aqui as implicações sociais e éticas tanto da atividade de pesquisa quanto daqueles que a conduzem.

Assim, podemos perceber com clareza como a perspectiva de "campo" exposta anteriormente coloca em xeque certa noção clássica de etnografia como deslocamento 
do pesquisador rumo a determinado locus (uma tribo, por exemplo) geográfico que funcionaria como espaço separado e demarcado de estudos. Por conseguinte, questiona ainda a tradicional separação epistemológica entre "nós" e "eles" (ou seja, entre "cientistas" e "nativos"), questionamento este que traz consigo nada desprezíveis consequências em termos das relações de poder que se estabelecem no trabalho junto a grupos das mais diversas naturezas. Diante de tal quadro, não nos parece descabido perguntar: estaria então a etnografia condenada ao esquecimento na contemporaneidade da pesquisa psicossociológica? $\mathrm{Ou}$ seria possível pensar de maneira menos excludente e mais conciliatória? É esta última hipótese que defenderemos nos parágrafos seguintes.

\section{Considerações finais}

Uma boa forma de encerrarmos (ao menos momentaneamente) essa reflexão que propusemos acerca da validade da utilização da etnografia na atualidade dos estudos psicossociológicos aparece na constatação de que, tanto histórica quanto epistemologicamente, a pesquisa de campo etnográfica consistiu em valiosa iniciativa por promover um estudo do outro a partir dos seus próprios termos. Isto causou uma verdadeira revolução nas ciências sociais, exposta pela possibilidade de que os elementos que compõem os diversos agrupamentos humanos (como direito, economia, religião, etc.) ao redor do mundo passassem a ser vistos de acordo com a sua coerência interna, ao invés de etnocêntrica e arbitrariamente tomados como simples recortes de um "exotismo" a ser comparado aos valores e práticas oriundas do Ocidente.

Da mesma maneira, não devemos desprezar o fato de que esse encontro mais próximo com o outro proporcionado pela etnografia, a despeito de ser, também ele, um filho da modernidade, possibilitou o fundamental questionamento da ideia de neutralidade e controle experimentais característica desta modernidade e do neopositivismo nela inserido. Com efeito, quer pretendesse isto ou não, Malinowski (1922/1978) propiciou a crítica a toda uma tradição cientificista no momento em que propôs uma observação participante que, além de pôr em xeque o cânone até então consagrado da separação entre sujeito e objeto do conhecimento, conduziu ainda ao reconhecimento de "imponderáveis" que desafiavam a lógica da razão instrumental.

Logo, não nos parece justo tratar hoje a etnografia apenas como espécie de vilã, já que encobridora das relações de poder presentes no trabalho de campo. Ora, ela também serviu e pode muito bem continuar servindo para o questionamento destas mesmas relações graças à flexibilidade que a caracteriza como instrumento de pesquisa. Esta flexibilidade, importante complementar, não deve ser confundida com omissão ou ausência de critérios para a coleta, validação e interpretação de dados, aparecendo sim como uma rica e, ao mesmo tempo, necessária contraposição entre o falado e o vivido no qual não cabe o estabelecimento de rígidos critérios ou pressupostos que, apressada ou imediatamente, agrupem um conjunto variado de fenômenos.

Nesse sentido, não custa lembrar que, ainda que Malinowski organizasse os seus estudos das diferentes esferas que compunham as práticas socioculturais das tribos trobriandesas a partir do pressuposto científico-funcionalista da existência de totalidades, estas não se apresentavam simplesmente como realidades homogêneas ou imanentes à espera de decifração ou representação. Isto pela simples razão de que este mesmo pressuposto da totalidade deveria ser cotidianamente reconstituído a partir de fragmentos fornecidos por diferentes vivências e atores sociais, daí a utilidade da complementação etnográfica como possibilidade de confrontação entre discurso e prática nativa.

Curiosamente, é ainda o pressuposto funcionalista de totalidade que originalmente caracterizou os primórdios da etnografia como prática científica que nos remete a uma segunda característica que nos faculta compreender o seu potencial crítico em relação às armadilhas impostas pelo discurso da razão instrumental. Tal dimensão se apresenta no componente intersubjetivo que caracteriza o trabalho do etnógrafo. Mas como será possível estabelecer uma relação entre a pretensão à objetividade científica característica de um funcionalismo totalizante e a dimensão intersubjetiva da experiência etnográfica que proporciona a crítica a este mesmo ideal?

Conforme exposto nos parágrafos anteriores, o conceito de etnografia como prática academicamente legitimável apareceu originalmente vinculado à perspectiva de uma apreensão integradora do universo nativo em termos de leis, atitudes e pensamentos. Ocorre que a própria figura do etnógrafo não ficou alheia a este processo. Afinal, com a utilização da observação participante, também ele (ou seja, o etnógrafo e as suas vivências, sentimentos e interpretações) passou a funcionar não apenas como instrumento de pesquisa, mas também como valiosa fonte de dados. Por conseguinte - e é aqui que se estabelece a curiosa dialética à qual nos referimos há pouco -, ao incluir o pesquisador como objeto de estudos, a pretensão funcionalista de cunho totalizante curiosamente terminou por favorecer a presença da subjetividade em meio ao seu ideal de objetividade científica, plantando assim a semente da crítica a este mesmo ideal.

Dessa maneira, utilizando uma expressão razoavelmente conhecida no meio acadêmico, será que devemos "jogar fora o bebê com a água do banho"? A resposta, a nosso ver, é não, já que, a despeito das suas origens no ideal cientificista que marcou a transição do século XIX ao XX, no momento em que passa a levar em conta as dimensões concomitantemente histórica e intersubjetiva do conhecimento sobre o outro - as quais, evidenciando o caráter simultaneamente provisório e particular de tal conhecimento, apontam os limites do próprio projeto científico moderno -, a etnografia mantém a sua riqueza como fonte de estranhamento, como meio para um exercício alteritário potencialmente revelador.

Nesses termos, outro reforço para a nossa argumentação em prol de uma possível complementaridade entre a 
etnografia e as novas propostas ético-metodológicas atualmente em voga em áreas como a psicologia social aparece no próprio fato de que, como afirma Montero (1996), uma parte nada desprezível da atual crítica ao realismo ontológico característico da modernidade foi desenvolvida por movimentos sociológicos, antropológicos e psicossociológicos provenientes desta modernidade e que, no entanto, foram capazes de remar contra a maré dominante. Desta maneira, a ênfase contemporânea nas relações de poder que, assim como em outras tantas atividades humanas, também se fazem presentes na pesquisa de campo não representa necessariamente uma ameaça ao etnógrafo, podendo sim ser tomada por ele como aliada rumo a novos e criativos experimentos no trato com a diferença.

É o que podemos deduzir da leitura dos trabalhos de Viveiros de Castro $(2002,2004)$ e Goldman $(2003,2008)$, os quais, a partir das suas próprias experiências etnográficas, bem como da leitura e reinterpretação de noções como as de "rede" (Deleuze \& Guattari, 1980), "reversibilidade" (Wagner, 1981), "reflexividade" (Strathern, 1988) e "simetria" (Latour, 1989, 1991) passam a nos interessar mais de perto à medida que vêm propondo novas alternativas para esse debate acerca das possibilidades e limites da representação da alteridade. Tais alternativas aparecem expressas, por exemplo, na aposta de uma antropologia "pós-social" em que o contato não se daria apenas ou prioritariamente entre teorias etnológicas, mas entre dados etnográficos provenientes de campos diversos, mas que poderiam se revelar fecundos uns para os outros (Viveiros de Castro \& Goldman, 2012). Isto tanto no sentido da criação de novas ideias e linhas de fuga quanto no que se refere às reavaliações de tradicionais noções que, apesar de úteis, correriam o sério risco de se cristalizar (como aquelas de "sujeito", "objeto", "cultura" e, importante, "identidade").

Ou seja, apresenta-se na antropologia "pós-social" de Viveiros de Castro e Goldman (2012) a defesa de uma espécie de perspectivismo que desobjetifica palavras e coisas, visando com isto refrear pelo menos parte da mania de especialização tradicionalmente presente em nosso contexto acadêmico. Para tanto, seguindo uma linha de pensamento próxima àquela anteriormente defendida por Favret-Saada (1977, 1990), os autores enfatizam a possibilidade de que nos deixemos afetar pelo frescor da precedência, do estranhamento ou da materialidade potencialmente gerados pela etnografia, valorizando não somente o confronto entre categorias próprias a diferentes especialidades acadêmicas (que, no entanto, poderiam se fazer conectar por matrizes de inteligibilidade e/ou inspirações conceituais em comum), mas também o entrechoque entre as categorias nativas e as nossas. Tudo isto elevado a um grau tal que nos permita alcançar pontos de "comutação" - isto é, passagens criativas em que tais instrumentos heurísticos possam resignificar uns aos outros.

Um complemento imediato e, ao mesmo tempo, bastante interessante dessa transversalidade antropológica proposta por Viveiros de Castro e Goldman (2012) aparece, então, na sua crítica à chance de que, por um lado, permaneçamos presos à tradição de procurar verdades ou explicações supostamente ocultas para o que os nativos dizem e, por outro, que levemos a sério demais a interdição, mais ou menos velada, de falar dos outros simplesmente como outros $^{5}$. Com efeito, por que devemos necessariamente escolher uma destas duas alternativas quando, ao invés disto, podemos nos deixar afetar mais, ouvindo o que os nativos têm a dizer já como explicações sem que isto signifique acreditarmos ingenuamente em tudo o que nos é dito? Não é, portanto, necessário escolher. E tal escolha não se faz necessária simplesmente porque, ao invés de percebermos aí polos opostos ou exclusivos, torna-se bem mais interessante que nos concentremos no trânsito entre discursos, categorias e lugares de pesquisador e de nativo, todos eles passíveis de mutações e mútua influência.

Evidentemente, isso não significa desconhecer o fato de que os grupos frequentados por pesquisadores e nativos possam apresentar óbvias disparidades em termos de poder, mas sim que devemos considerar seriamente a possibilidade de que o trabalho etnográfico adquira a capacidade (quer seja na antropologia ou na psicologia social) de situar ambos os discursos, isto é, aquele da sociedade do pesquisador e aquele outro da sociedade do nativo (lembrando aí que costuma ocorrer com bastante frequência deste encontro se dar em uma mesma sociedade) como igualmente diferentes. Isto significa evitar ao máximo a adoção ou reafirmação de poderes a priori, procurando aproximações da alteridade que não caiam nem na naturalização de dados e na ocupação de lugares um tanto congelados e nem tampouco na tentação relativista de pesarmos a mão demasiadamente em nossos próprios umbigos de "sujeitos" ou "autores" que assinam textos sobre os outros.

Em outros termos, trata-se de pensar a etnografia a partir do provisório, de uma multiplicidade que abole tanto dualismos estanques quanto garantias prévias de síntese, promovendo uma circulação do(s) sentindo(s) entre polos intercambiáveis. Em tal movimento, talvez possamos construir uma esperançosa ponte para algo mais: uma reordenação, realinhamento ou, melhor ainda, "embaralhamento" do(s) dualismo(s) com os quais tanto "nós" quanto "eles" costumeiramente travamos os nossos contatos. E se, como sabiamente afirmou Strathern (1988), tal tarefa se revela, no limite, impossível, isto não precisa necessariamente significar o silêncio sobre a sua urgência.

Certamente muito ainda haveria por ser dito. De qualquer forma, finalizamos com a perspectiva de que a experiência de estranhamento que tradicionalmente caracterizou a etnografia continua trazendo em si mesma tanto o dinamismo quanto o potencial crítico necessários para manter em movimento o pensamento sobre (ou, se preferirmos, com) as diferenças. Logo, reafirmando com outras palavras a argumentação central do presente artigo, não se trata simplesmente de profetizarmos os limites ou mesmo o fim da prática etnográfica, descartando-a como ultrapassada

5 Afinal, a diferença, na contemporaneidade de importantes setores de uma antropologia como a norte-americana, por exemplo, parece haver se tornado um grave problema diante da obsessão com os riscos de uma "exotização" politicamente incorreta e conhecida como "othering". 
ou tendenciosa por supostamente funcionar apenas como instrumento perpetuador de desiguais relações de poder entre "observadores" e "observados", mas de atentarmos para as possibilidades dela decorrentes, inclusive quanto a sua utilização em conjunto com outras metodologias de pesquisa adotadas na contemporaneidade tanto da pesquisa antropológica quanto da psicossociológica

\title{
A question of method: Origins, limits and possibilities of ethnography to social psychology
}

\begin{abstract}
Focusing the subject of research methods in social psychology, this article gravitates around three objectives: to define in detail some of the main characteristics of ethnography, to review the historical background of its origins as a scientifically legitimated practice and, finally, to discuss its utilization nowadays. As a result, it emphasizes not only the limits, but also the possibilities of ethnographical practice, sustaining that the experience of strangeness that traditionally characterized it still carries the dynamics and the critical potential which are necessary to maintain in movement the thought about alterity.
\end{abstract}

Keywords: methodology, ethnography, alterity.

\section{Une question de méthode : origines, limites et possibilités de l'ethnographie pour la psychologie sociale}

Résumé: Cet article, tourné vers la méthodologie de recherche en psychologie sociale, a trois objectifs : définir en détail quelques-unes des principales caractéristiques de l'ethnographie, réaliser un bref parcours historique à partir de ses origines comme pratique scientifiquement légitime et, finalement, discuter de son utilisation aujourd'hui. De façon cloncluante, il met en relief non seulement les limites, mais aussi les possibilités de la pratique ethnographique, en défendant que l'expérience d'étrangeté qui l'a traditionnellement caractérisée continue porteuse en soi tant aussi bien du dynamisme que du potentiel critique nécessaires au maintien du mouvement de la pensée relative ou, si on le préfère, avec un regard différent.

Mots-clés : méthodologie, ethnographie, altérité.

\section{Una cuestión de método: orígenes, límites y posibilidades de la etnografía para la psicología social}

Resumen: Este artículo, dedicado a la metodología de pesquisa en psicología social, se organiza en torno de tres objetivos: definir en mayores detalles algunas de las principales características de la etnografía, realizar un breve histórico acerca de sus orígenes como práctica científicamente legitimada y, finalmente, discutir su actual utilización. Se concluye que enfatiza no solamente los límites, pero también las posibilidades de la práctica etnográfica, al sostener que la experiencia de extrañamiento que tradicionalmente la caracteriza sigue trayéndola tanto el dinamismo cuanto el potencial crítico necesarios para mantener en movimiento el pensamiento sobre o, si preferimos, con la diferencia.

Palabras clave: metodología, etnografía, alteridad.

\section{Referências}

Arendt, R. J. (2008). Maneiras de pesquisar no cotidiano: contribuição da teoria do ator-rede. Psicologia \& Sociedade, 20, 7-11.

Backès-Clément, C. (1988). Antropologia e psicanálise. In C. Backès-Clement, J. Copans, M. Godelier \& S. Tornay (Eds.), Antropologia: ciência das sociedades primitivas? (pp. 211-238, J. P. de Andrade, trad.). Lisboa: Edições 70.

Bastide, R. (1974). Sociologia e psicanálise (H. L. Dantas, trad.). São Paulo, SP: Melhoramentos. (Trabalho original publicado em 1950)

Clifford, J. (1988). The predicament of culture: Twentiethcentury ethnography, literature and art. Cambridge, MA: Harvard University Press.
Clifford, J., \& Marcus, G. (1986). Writing culture: The poetics and politics of ethnography. Berkeley, LA: University of California Press.

Coulon, A. (1995). A escola de Chicago (T. Bueno, trad.). Campinas, SP: Papirus.

Deegan, M. J. (2001). The Chicago school of ethnography. In P. Atkinson, S. Delamont, A. Coffey \& J. Lofland (Eds.), Handbook of ethnography (pp. 11-25). London: Sage.

Deleuze, G., \& Guattari, F. (1980). Mille plateaux. Paris: Éditions de Minuit.

Devereux, G. (1972). Ethnopsychanalyse complémentariste. Paris: Flammarion. 
Devereux, G. (1977). Essais d'ethnopsyquiatrie génerale. Paris: Gallimard.

Devereux, G. (1980). De l'angoisse a la méthode dans les sciences du comportement. Paris: Flammarion.

Durham, E. R. (1978). A reconstituição da realidade: um estudo sobre a obra etnográfica de Bronislaw Malinowski. São Paulo, SP: Ática.

Farr, R. M. (1999). As raízes da psicologia social moderna (2a ed., P. A. Guareschi \& P. V. Maya, trads.). Petrópolis, RJ: Vozes.

Favret-Saada, J. (1977). Les mots, la mort, les sorts. Paris: Gallimard.

Favret-Saada, J. (1990). Être affecté. Gradhiva: revue d'histoire et d'archives de l'anthropologie, 8, 3-9.

Firth, R. (1960). Man and culture: an evaluation of the work of Bronislaw Malinowski. London: Routledge \& Kegan Paul.

Geertz, C. (1973). The interpretation of cultures: selected essays. New York: Basic Books.

Godelier, M., \& Hassoun, J. (1996). Meurtre du pére, sacrifice de la sexualité: approches anthropologiques et psychanalytiques. Paris: Éditions Arcanes.

Goldman, M. (2003). Os tambores dos mortos e os tambores dos vivos. Etnografia, antropologia e política em Ilhéus, Bahia. Revista de Antropologia, 46(2), 445-476.

Goldman, M. (2008). Os tambores do antropólogo: antropologia pós-social e etnografia. Ponto Urbe Revista do Núcleo de Antropologia Urbana da USP, 2. Recuperado de http://www.n-a-u.org/pontourbe03/ Goldman.html

Gonçalves Filho, J. M. (2003). Problemas de método em psicologia social: algumas notas sobre a humilhação política e o pesquisador participante. In A. M. Bock (Org.), Psicologia e compromisso social (pp. 193-239). São Paulo, SP: Cortez.

Kastrup, V. (2007). O funcionamento da atenção no trabalho do cartógrafo. Psicologia \& Sociedade, 19(1), 15-22.

Kleinman, A. (1996). Writing at the margin: Discurse between anthropology and medicine. California: University of California Press.

Kuper, A. (1978). Malinowski. In A. Kuper, Antropólogos e antropologia (A. Cabral, trad., pp. 11-50). Rio de Janeiro, RJ: Francisco Alves.

Latour, B. (1989). Science in action. Cambridge: Harvard University Press.

Latour, B. (1991). Nous n'avons jamais été modernes: essai d'anthropologie symétrique. Paris: La Découverte.

Lévi-Strauss, C. (1958). Anthropologie structurale. Paris: Plon.

Lévi-Strauss, C. (1962). Le totémisme aujourd'hui. Paris: PUF.

Magnani, G. C. (2009). Etnografia como prática e experiência. Horizontes Antropológicos, 32, 129-156.

Malinowski, B. (1973). Sexo e repressão na sociedade selvagem (F. M. Guimarães, trad.). Petrópolis, RJ: Vozes. (Trabalho original publicado em 1927)
Malinowski, B. (1978). Argonautas do pacífico ocidental (A. P. Carr \& L. A. Cardieri, trads.). São Paulo, SP: Abril Cultural. (Trabalho original publicado em 1922)

Marcus, G., \& Fischer, M. (1986). Anthropology as cultural critique: an experimental moment in the human sciences. Chicago: The University of Chicago Press.

Montero, M. (1996). Paradigmas, corrientes y tendencias de la psicología social finisecular. Psicologia \& Sociedade, $8(1), 102-119$.

Narita, S. (2006). Notas de pesquisa de campo em psicologia social. Psicologia \& Sociedade, 18(2), 25-31.

Rock, P. (2001). Symbolic interactionism and ethnography. In Atkinson, P., Coffey, A., Delamont, S., Lofland, J., \& Lofland, L. (Eds.), Handbook of ethnography (pp. 2638). London: Sage.

Róheim, G. (1967). Psychanalyse et anthropologie. Paris: Gallimard.

Sato, L., \& Souza, M. P. (2001). Contribuindo para desvelar a complexidade do cotidiano através da pesquisa etnográfica em psicologia. Psicologia USP, 12(2), 29-47.

Silva, R. N. (2004). Notas para uma genealogia da psicologia social. Psicologia \& Sociedade, 16(2), 12-19.

Spink, M. J. (2007). Pesquisando no cotidiano: recuperando memórias de pesquisa em psicologia social. Psicologia \& Sociedade, 19(1), 7-14.

Spink, P. K. (2003). Pesquisa de campo em psicologia social: uma perspectiva pós-construcionista. Psicologia \& Sociedade, 15(2), 18-42.

Stocking Junior, G. (1992). The ethnographer's magic: Fieldwork in British anthropology from Tylor to Malinowski. In G. Stocking Junior, The ethnographer's magic and other essays in the history of anthropology (pp. 12-59). Madison: The University of Wisconsin Press.

Strathern, M. (1988). The gender of the gift: Problems with women and problems with society in Melanesia. Berkeley: University of California Press.

Tittoni, J., \& Jacques, M. G. (1998). Pesquisa. In M. N. Strey (Org.), Psicologia social contemporânea (pp. 73-85). Petrópolis, RJ: Vozes.

Viveiros de Castro, E. (2002). O nativo relativo. Mana, 8(1), 113-148.

Viveiros de Castro, E. (2004). Perspectival anthropology and the method of controlled equivocation. Tipiti: Journal of the Society for the Anthropology of Lowland South America, 2(1), 3-22.

Viveiros de Castro, E., \& Goldman, M. (2012). Introduction to post-social anthropology: networks, multiplicities, and symmetrizations. HAU: Journal of Ethnographic Theory, 2(1), 421-433.

Wagner, R. (1981). The invention of culture. Chicago: University of Chicago Press. 